Journal of Agricultural Sciences
(Tarim Bilimleri Dergisi)

\title{
The Effects of Unsaturated Fatty Acid Supplementation to Ration on Superovulation Performance and Embryo Quality of Donor Cows
}

\author{
Serdal ÇOBAN ${ }^{a *} \mathbb{D}$, Zeynep ERDOĞAN ${ }^{b}$ (D) \\ ${ }^{\boldsymbol{a}}$ Republic of Turkey Ministry of Agriculture and Forestry-Eastern Mediterranean Agricultural Research Institute, Adana, TURKEY

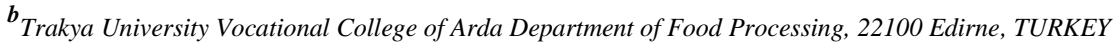 \\ ARTICLE INFO \\ Research Article \\ Corresponding Author: Serdal ÇOBAN, E-mail: serdalcoban@hotmail.com \\ Received: 11 September 2019 / Revised: 09 January 2020 / Accepted: 11 January 2020 / Online: 31 May 2021
}

\section{ABSTRACT}

This study was conducted to determine the effects of omega- 3 ( $\alpha$ linolenic acid) fatty acid supplementation to donor cow rations on superovulation performance, embryo number and quality, and bloodprogesterone levels. The study was carried out with two groups, each consisting of 10 black-and-white breed dairy cows. Control group was fed with the basic ration prepared, and the experimental group was fed with the ration added with omega- 3 polyunsaturated fatty acid (PUFA) source at a level of $3.82 \%$ of the basic ration dry matter (DM) for 60 days training period. Thus, each of experimental group's cow consumed 900 g-day feed additives consisting $149.4 \mathrm{~g}$ omega-3 daily. The superovulation protocol was started at the $40^{\text {th }}$ day of feeding period. According to the findings of the study, the difference between the

Keywords: Donor cow; Embryo number; Flaxseed; Omega-3; Quality; Superovulation performance groups in terms of the response to superovulation was found to be insignificant $(\mathrm{P}>0.05)$. Similarly, there was no significant difference in blood progesterone levels between the groups $(\mathrm{P}>0.05)$. However, the difference between the control group and the experimental group in terms of transferable and non-transferable embryo rates was found to be significantly important $(\mathrm{P}<0.05)$. The total number of transferred embryos was determined as 37 in the experimental group and 79 in the control group. The total number of non-transferable embryos was recorded as 78 in the trial group and 43 in the control group. At the end of the study, it was concluded that supplementation to donor cow rations with omega-3 fatty acid sources might have a negative effects on transferrable embryo number and quality.

(c) Ankara University, Faculty of Agriculture

\section{Introduction}

Embryo transfer applications are one of the main techniques for making progress in animal breeding. Success in embryo transfer depends on the response of the donor animal to the superovulation and the number and quality of embryos obtained (Bülbül \& Dursun 2005). There are many factors affecting the success of superovulation and also the quality of oocytes and embryos (Hasler 2004). These factors include; related to the animal (age, race, genetics, state of the follicles, lactation, etc.), drugs administered, feeding and other environmental factors (temperature, maintenance etc.) (Bülbül \& Dursun 2005; Kaymaz 2015).

Nutritional factors may be the most important because they can directly affect reproductive performance and have the ability to change the effects of other factors (Smith \& Akinbamijo 2000). Indeed, numerous studies have reported that nutrition of donor cows has an effect on the number and quality of embryos in response to superovulation (Boland \& Lonergan 2003; Takahashi et al. 2013).

There is a highly complex relationship between nutrition and reproduction. The energy-protein, and mineral-vitamin balance should be well established in dairy cattle (Ergün \& Erdoğan 2001).

The energy content of the ration is the most important nutritional factor affecting milk yield, living weight and associated body condition score (BCS) and reproductive function (Boland \& Lonergan 2003). One way to improve the energy balance and thus fertility in the early period of lactation is to increase the energy density of the rations by the addition of fat (Staples et al. 1998).

In recent years, it has been accepted that the positive effects of the addition of fat to the ration on fertility are not due to the improvement in the energy status of the cows, but due to the use of high amounts of specific fatty acids (Mattos et al. 2000; Santos et al. 2008; Leroy et al. 2013). In this case, the most emphasized issue has been long-chain unsaturated fatty acids which are omega-3, omega-6 and conjugated linoleic acid (CLA) (Şirin \& Kuran 2004; Elis et al. 2016). 
Essential fatty acids have important roles in reproductive functions. Because fatty acids are involved in the synthesis of the hormones such as progesterone and prostaglandin $\left(\mathrm{PGF}_{2 \alpha}\right.$ and PGE2). Arahidonic acid is a precursor of prostaglandin hormones $\left(\mathrm{PGF}_{2 \alpha}\right.$ and PGE2). Linoleic acid (omega-6) is also the precursor of arachidonic acid. Cholesterol is the main precursor to progesterone. Linolenic acid (omega-3) also plays a role in the synthesis of progesterone, as it is a precursor to cholesterol (Mattos et al. 2000; Urlep \& Rozman 2013; Tessaro et al. 2015). Indeed, it has been reported that blood progesterone levels increase in cows fed with rations rich in linolenic acid (Mattos et al. 2000). Increased progesterone concentrations during superovulation improve embryo quality and the number of transplantable embryos. The decrease in blood progesterone levels leads to the ovulation of low-quality oocyte, premature onset of meiosis cleavage, and an increase in LH release (Hiçcan \& Yıldız 2016). It has also been reported in a study that high progesterone concentration during superovulation application improves embryo quality collected on day 7 after superovulation (Rivera et al. 2011).

There are many studies reporting the effect of feeding on reproduction in cows. Most of these studies show that there is a relationship between feeding and reproduction. The effects of specific nutrients on key issues such as superovulation response in donor cows, oocyte and early embryo development and quality, and conception after embryo transfer are still unclear (Salehi et al. 2016).

The present study aimed to investigate the possible effects of omega-3 fatty acid addition source to the ration of donor cows on follicle development, superovulation performance and quality and number of embryos obtained from the application. Thus, it is aimed to contribute to the literature on the relationship between fertility and fat source added to the ration in donor cows.

\section{Material and Methods}

This study was carried out in the Department of Animal Breeding of the Eastern Mediterranean Agricultural Research Institute. In this study, a total of 20 Holstein cows having similar live weight (500-550 kg), similar body condition score (2.7-3.0), and free of uterine infections and contagious diseases were used as animal material. The cows used in the trial were at 8-20 weeks of lactation period. The animals were composed with similar lactation age (2-3) and similar milk yield (average $28 \mathrm{~kg} / \mathrm{day}$ ). The cows were in 42-54 months of ages.

Mustafa Kemal University, Animal Experiments Local Ethics Committee's decision dated 15.07.2015 and numbered 2015, 6-11 was approved for conducting the study.

\subsection{Supply of feed materials and additives}

The concentrate feeds used in Total Mixed Ration (TMR) were prepared in Feeds Unit of East Mediterranean Agricultural Research Institute. Silage and wheat straw were sourced from the farmland owned by the Institute. Vetch dry grass was purchased from the market.

A commercial product called Flaxpro ${ }^{\circledR}$ (Volac International Limited, UK) was used as an additive in the trial Group. The additive containing flaxseed was used as an omega-3 source (C18:3 n-3 linolenic acid) from polyunsaturated fatty acids. The product, which is not commercially available in Turkey, was imported with the support of the firm. Flaxpro ${ }^{\circledR}$ is an energy intensive product (23 MJ-kg KM) consisting of a combination of rumen-protected oil and omega-3 fatty acid-rich flaxseed. In addition, the product has a content of 50\% crude oil (CO) and C18:3 n-3 linolenic acid at a rate of $166 \mathrm{~g}-\mathrm{kg}$ (Table 1).

Table 1- Composition of the additive used in study (\%)

\begin{tabular}{ccccccc}
\hline $\begin{array}{c}\text { DM } \\
(\text { Dry Matter })\end{array}$ & $\begin{array}{c}\text { CO } \\
(\text { Crude Oil })\end{array}$ & $\begin{array}{c}\text { CP } \\
\text { (Crude Protein) }\end{array}$ & $\begin{array}{c}\text { CF } \\
\text { (Crude Cellulose })\end{array}$ & Ash & Ca & $\begin{array}{c}\text { ME } \\
(\text { MJ-kg DM })\end{array}$ \\
\hline 96 & 50 & 15 & 7.5 & 8 & 5 & 23 \\
\hline
\end{tabular}

\subsection{Feeding of animals}

The study was conducted with control and experimental groups. Experimental group fed with TMR added with supplement as omega-3 fatty acid source. A total of 20 cows were divided into two groups each has 10 black-and-white breed dairy cows. In the study, the animals were fed individually with TMR, which included coarse and concentrated mixed feeds (Table 2). The composition of the TMR used in the experiment was analysed according to the method reported in AOAC (AOAC 1998).

The animal trial period of the study took a total of 60 days, including 10 days pre-feeding period +30 days feeding period +20 days superovulation protocol and uterine washing period. The experimental feeding was continued during superovulation applications. 
Table 2- Composition and nutrient content of TMR fed to animals in study

\begin{tabular}{|c|c|c|}
\hline Ingredients & Control group \%, DM & Trial group \%,DM \\
\hline Corn silage & 26.50 & 27.04 \\
\hline Wheat straw & 12.00 & 14.36 \\
\hline Vetch dry grass & 13.73 & 14.09 \\
\hline Barley & 10.20 & 10.47 \\
\hline Maize & 23.54 & 13.25 \\
\hline The additive & - & 3.82 \\
\hline Corn gluten & 1.86 & 1.91 \\
\hline Soybean meals & 11.59 & 11.89 \\
\hline Wheat bran & - & 3.07 \\
\hline Limestone & 0.5 & 0.04 \\
\hline Salt & 0.04 & 0.04 \\
\hline Vit-min. mix* & 0.04 & 0.04 \\
\hline \multicolumn{3}{|l|}{ Nutrient content, $\%$} \\
\hline $\mathrm{DM}, \%$ & 51.5 & 51.10 \\
\hline $\mathrm{CP}, \% \mathrm{DM}$ & 15.1 & 15.1 \\
\hline $\mathrm{CO}, \% \mathrm{DM}$ & 3.27 & 6.24 \\
\hline Omega-3; \% DM & - & 0.66 \\
\hline Omega-3 g / day-head & - & 149.4 \\
\hline NDF, \% DM & 38.1 & 38.3 \\
\hline $\mathrm{ADF}, \% \mathrm{DM}$ & 23.3 & 23.4 \\
\hline NEl, Mcal kg-1 DM & 35.21 & 35.21 \\
\hline DM kg / day: & 23.2 & 22.6 \\
\hline Roughage / concentrated & 52.1 & 55.4 \\
\hline
\end{tabular}

*Vitamin-mineral mix; Vitamin A: $12.000 .000 \mathrm{IU}$, Vitamin $\mathrm{D}_{3}: 240.000 \mathrm{IU}$, Vitamin E: $5.000 \mathrm{mg}$, Vitamin B1: $500 \mathrm{mg}$, Vitamin B6: 1.000 mg, Niacin: 40.000 mg, Folic Acid: 100 mg, D-Biotin: 200 mg, Antioxidant: 3.500 mg; Cu: 6.000 mg; Zn: 15.000 mg; Fe: 10.000 mg; MCP P: 65.000 mg; I: 100 mg; Co: 40 mg; mg: 20.000 mg; Mn: 15.000 mg; Se: 200 mg; $\mathrm{CaCO}_{3}$ : 598.150 mg; Organic Se: 50 mg; Organic Fe: 4.000 mg; Organic Cu: 2.000 mg; Organic Zn: $8.000 \mathrm{mg}$; Organic Mn: $6.000 \mathrm{mg}$; Active yeast: 4x10 ${ }^{10}$; Beta carotene: $4.000 \mathrm{mg}$; Vanilla aroma: $7.000 \mathrm{mg}-5 \mathrm{~kg}$ mix.

The control and experimental group rations used in the study were prepared as isocaloric and isonitrogenic (Table 2). When preparing the rations, the groups' average live weight, milk yield, milk fat content, body condition score values were taken into consideration and nutrient requirement and dry matter consumption were calculated through the formulas defined by NRC (NRC 2001). By using these calculated values, TMR was formed by balancing the roughage - concentrate feed ratio to at least 40-60 and maximum 60-40. Daily feed consumption of animals was determined during the exercise period. The average $40 \mathrm{~kg}-$ day TMR per animal- was given. The prepared rations were divided into two equal amounts by weighing, and were given in two meals, at 06.30 in the morning and 18.30 in the evening.

\subsection{Superovulation protocol}

The uterus and ovariums of the donor cows to be used in the study were examined for pathological or cystic structures with ultrasound (Ultrasonic Scanner, HS-101V, Honda, Japan) before starting the feeding program.

The controlled drug released instrument (PRID Delta, Ceva, Turkey) which is the most preferred method (1.55 $\mathrm{g}$ progesterone) underwent intravaginal in order to synchronize follicular development prior to superovulation programs. On the $7^{\text {th }}$ day of intravaginal implant administration, FSH (Folltropin-V, Bionech Animal Health Europe Ltd., Ireland) hormone injection was started (Bó et al. 2002). FSH hormone injections were administered intramuscularly (i.m.) in decreasing amounts of 4-4, 3-3, 2-1.5, 1.5-1 cc, twice in 12 hours intervals for 4 days (Kaymaz 2015). At the day of 3 and -4 of the superovulation protocol, 2 cc PGF $_{2 \alpha}$ (50 mg cloprostenole, Lutelen, Topkim, Turkey) was injected twice with 24 hours intervals to regress the existing corpus luteum and to ensure ovulation. The controlled drug release material (PRID) was removed at the evening of 3 rd day of FSH hormone application. At the 12th, 24th and 48th hours following the last FSH administration, donor cows with estrus were inseminated 3 times (Bó et al. 2002). On the seventh day after the last artificial insemination following the superovulation protocol, the animals were subjected to uterine washing (flushing). On the day of washing of uterus, ovaries were examined with ultrasound (Ultrasonics Convex Scanner, HS-2000, Honda, Japan), and the number and size of corpus luteum on both ovaries were recorded. The superovulation response of the groups was evaluated by the presence of corpus luteum on both ovaries (Albuquerque et al. 2012). At the end of the study superovulation and fertilization rates of groups were calculated as shown below (Childs et al. 2008; Tur 2014).

Superovulation rate: $100 \mathrm{x}$ (the number of corpus luteum with two or more per cow / total number of cows)

Fertilization rate: $100 \mathrm{x}$ (total number of embryos / total number of cell)

\subsection{Search and evaluation of embryos}

The washing solution brought to embryo transfer laboratory after uterine washing process was examined under a stereo 
microscope (Leica, s8apo, Japan) in $90 \mathrm{~mL}$ search Petries (Agtech Square Search Dish, VWR, USA). They were classified according to the quality criteria (IETS 2010) and developmental stages (Kanagawa et al. 1995) determined by the International Embryo Transfer Society (IETS).

\subsection{Hormone analysis}

Blood samples were taken from the 20 donor cows used in the study for the purpose of progesterone hormone analysis. Blood

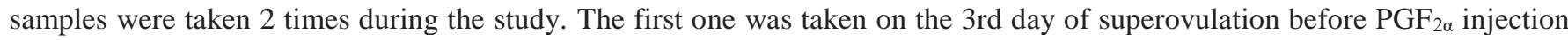
and the second one was taken on the flushing day. Blood progesterone levels were measured by Chemmilunesons method using the DXI800 hormone analyzer (Beckman Coulter, California, USA) and Beckman Coulter progesterone kit at the Balcali Hospital Central Laboratory of Cukurova University.

\subsection{Statistical analysis}

In the present study, Student $\mathrm{t}$ test, Mann Whitney U test and $\mathrm{z}$ test were used to compare the data obtained from the groups. Comparison of embryo numbers obtained in Group 1 and Group 2 was performed using Chi-Square test. SPSS 11.5 package program was used to evaluate the data (SPSS 1999).

\section{Results and Discussion}

Embryos classified as $1^{\text {st }}, 2^{\text {nd }}$ and $3^{\text {rd }}$ quality were assessed as transferable embryos, while degenerate embryos and unfertilized oocytes (UFO) and degenerate oocytes were accepted as non-transferable embryos. The number of embryos obtained in the experimental groups are shown in Table 3.

Table 3- The number of transferable and non - transferable embryo, UFO, degenerate oocyte, total embryo and total cell numbers of experimental groups

\begin{tabular}{ccccccc}
\hline Groups & $\begin{array}{c}\text { Transferable } \\
\text { embryo }\end{array}$ & $\begin{array}{c}\text { Non- } \\
\text { transferable } \\
\text { embryo }\end{array}$ & UFO & $\begin{array}{c}\text { Degenerate } \\
\text { oocyt }\end{array}$ & $\begin{array}{c}\text { Total } \\
\text { embryo }\end{array}$ & $\begin{array}{c}\text { Total cell } \\
\text { numbers }\end{array}$ \\
\hline Experiment & $37^{\mathrm{b}}$ & $78^{\mathrm{a}}$ & 4 & $56^{\mathrm{a}}$ & 55 & 115 \\
Control & $79^{\mathrm{a}}$ & $43^{\mathrm{b}}$ & 9 & $12^{\mathrm{b}}$ & 101 & 122 \\
\hline
\end{tabular}

*, Total cell numbers; indicates the number of oocytes and embryos obtained.

A total of 23 first quality, 12 second quality, 2 third quality and 18 degenerate embryos were obtained in the experimental group. In the control group, 60 first quality, 18 second quality, 1 third quality and 22 degenerate embryos were obtained. The number of unfertilized oocytes (UFO) was recorded as 4 in the experimental group and 9 in the control group. The number of degenerated oocytes was determined as 56 in the experimental group and 12 in the control group.

The results obtained from the two of research groups were compared with the Chi-Square test in terms of degenerate embryo numbers and degenerate oocyte numbers, There was no statistically significant difference between the groups in terms of degenerate embryo rates $(\mathrm{P}>0.05)$. However, a statistically significant difference was found between the groups in terms of degenerate oocyte rates $(\mathrm{P}<0.05)$. The number of degenerated oocytes in the experimental group were found to be higher than the control group.

Similarly, the numbers of transferable embryos and non-transferable embryos between the groups were compared with the Chi-Square test. There was a statistically significant difference between the control group and the experimental group in terms of transferable and non-transferable embryo rates $(\mathrm{P}<0.05)$. The number of transferable embryos was detected higher in the control group than in the experimental group. However, the number of non-transferable embryos was detected lower in the control group than in the experimental group.

The comparison of the mean blood progesterone levels of experimental and control groups are shown in Table 4. There was no statistically significant difference between the progesterone levels of the groups at the flushing day and during superovulation $(\mathrm{P}>0.05)$.

Table 4- The mean blood-progesterone levels $\left(\mathrm{ng} \mathrm{mL}^{-1}\right)$ of the experimental groups

\begin{tabular}{lll}
\hline Groups & $X \pm$ Sx (during superovulation) & $X \pm$ Sx (flushing day) \\
\hline Experiment & $1.06 \pm 0.39$ & $6.79 \pm 1.12$ \\
Control & $2.19 \pm 0.48$ & $10.04 \pm 2.45$ \\
\hline
\end{tabular}


The ovaries of the donor cows in both groups were examined by ultrasound on flushing day and the comparison of the average number and size of the average corpus luteum detected are given in Table 5.

Table 5- The mean corpus luteum numbers and size ( $\mathrm{mm})$ of experimental groups

\begin{tabular}{lcc}
\hline Groups & $X \pm S x(C L$ numbers $)$ & $X \pm S x(C L$ size $)$ \\
\hline Experiment & $14.10 \pm 2.11$ & $15.79 \pm 0.63$ \\
Control & $14.67 \pm 3.03$ & $14.78 \pm 0.45$ \\
\hline
\end{tabular}

The corpus luteum numbers of the experimental and control groups were compared using Mann Whitney U test and corpus luteum sizes by Student $\mathrm{t}$ test. There was no statistically significant difference between groups in terms of corpus luteum number and size of both groups $(\mathrm{P}>0.05)$.

While all cows included in the experimental group responded to superovulation, only 9 cows responded to superovulation in the control group. The response rates of superovulation between the groups were compared with $\mathrm{z}$ test (hypothesis test of difference of rates). The difference between the groups in terms of response rates to superovulation was found to be insignificant $(\mathrm{P}>0.05)$. Superovulation responses of the groups are shown in Table 6.

Table 6- Superovulation Response and Fertilization Rates (\%) of Groups

\begin{tabular}{lcc}
\hline Parameters & Trial group & Control group \\
\hline Total Cows & 10 & 10 \\
Number of Cows Flushing & 10 & 9 \\
Response to Superovulation (\%) & 100 & 90 \\
Fertilization Rate (\%) & 47.8 & 82.7 \\
\hline
\end{tabular}

The fertilization rates of the groups were determined by the ratio of the total number of embryos obtained to the total number of cells. According to this data; the fertilization rate was $47.8 \%$ in the experimental group and $82.7 \%$ in the control group. Fertilization rates were compared with $\mathrm{z}$ test (hypothesis test of difference of rates). A statistically significant difference was observed when the fertilization rates were compared between the experimental and control groups, $(\mathrm{P}<0.05)$. The fertilization rates of the groups are shown in Table 6 .

In the present study, the effect of the omega-3- rich supplementation to donor cows rations on the number and quality of oocytes and embryos was examined. The total number of cells in terms of oocytes and embryos obtained as a result of the study were determined similar to each other in both groups (experimental group: 115; control group: 122). In donor cows fed with omega-3 source, the number of embryos of transferable quality was recorded lower than the control group. It was interpreted that this difference in transferable embryo numbers between the groups may have been due to the high number of degenerate oocytes and low rates of fertilization in the experimental group. Actually, when the numbers of degenerate oocytes and fertilization rates were compared between the groups, the difference was found to be statistically significant $(\mathrm{P}<0.05)$. While the number of degenerate oocytes obtained in the experimental group was 56, it was recorded as 12 in the control group. However, the fertilization rates were determined as $47.8 \%$ in the experimental group and $82.7 \%$ in the control group.

The results of the present research show no resemblance to the reports of Childs et al. (2008), Petit et al. (2008) and Albuquerque et al. (2012)'s in terms of fertilization rates. Childs et al. (2008), Petit et al. (2008) and Albuquerque et al. (2012) have reported that the addition of n-3 polyunsaturated fatty acids to rations did not affect the number of unfertilized oocytes (UFO) $(\mathrm{P}>0.05)$. In the present study, low fertilization rates depending on the high number of unfertilized oocytes is due to the high number of degenerate oocytes in the total number of cells obtained.

While the results of the present study were compatible with Petit et al. (2008) it is different from the results of Childs et al. (2008), Muller et al. (2009), Albuquerque et al. (2012) and Salehi et al. (2016). Albuquerque et al. (2012) found that the average number of the degenerate embryos was statistically higher $(\mathrm{P}<0.10)$ in the flaxseed fed group than in the control group in Nellore cattle. Childs et al. (2008), investigated the effects of n-3 polyunsaturated fatty acid supplementation on embryo yield and quality in heifer rations. They found that the number of degenerated embryos obtained in heifers fed with n-3 PUFA was lower than the control group at the end of their study.

The reasons of different results in terms of degenerate embryo numbers, reported in the previous studies might be due to physiological characteristics of donor cows used in the studies (being a heifer or cow, lactation period, etc.) and breeds of the cows might also affect the results. 
It could be said that based on to the data obtained from this study, the addition of omega-3 rich unsaturated fatty acid to donor cow rations do not have a positive effect on the number of oocytes and number of transferable quality embryos. The effect of unsaturated fatty acids on embryo quality was investigated in some in vitro studies. Fouladi-Nashta et al. (2007), reported that linolenic acid had a positive effect on oocyte and embryo development. However, it has been found that feeding with linolenic acid-rich ration has no positive effect on oocyte and embryo development in donor cows in some of the abovementioned in vivo studies. In this case, it is thought that ovulation may be delayed in superovulated donor cows fed with omega-3 rich ration.

As it is known, a delay in ovulation in cows could lead to low fertility. In this study, it was estimated that the decrease in oocyte quality and fertilization rates may be caused by delay in ovulation. The reason for the decrease in fertility rate due to the delay of ovulation can be explained by aging of the oocyte within the follicle and slow embryo development and early embryonic death and consequently decrease in fertilization. Indeed, it has been reported by Bidarimath \& Glover (2015) that ovulation was delayed in cows fed by omega-3-rich rations and this finding supports our results.

Bidarimath \& Glover (2015) reported that long-chain unsaturated fatty acids added to the diets may directly or indirectly affect LH waves and estradiol secretion before ovulation. Under normal circumstances, when the estradiol concentration reaches a threshold or peak, the anterior lobe of the pituitary is stimulated to secrete GnRH. In the present study, depending on this information, it is thought that ovulation delays may be due to delay in LH fluctuation and this delay may be caused by insufficiency in estradiol release. Some other studies have also reported that the addition of unsaturated fatty acid sources to dairy cow rations leads to a decrease in plasma estrodiol levels (Fouladi-Nashta et al. 2007).

In this study, the number and dimensions of corpus luteum detected on flushing day were compared in order to evaluate the superovulation performance of both groups. The total number of corpus luteum on both ovaries was accepted as 2 or more in order to develop a response to superovulation in donor cows (Tur 2014). Accordingly, all of the donor cows from the experimental group used in the present study responded to superovulation. However, when the responses of the cows in control and experimental groups to the superovulation applications were compared statistically, the difference between the two groups was found to be insignificant $(\mathrm{P}>0.05)$. In addition, no statistically significant difference was found between the experimental and control groups in terms of the number and size of corpus luteum $(\mathrm{P}>0.05)$. In this study, it was found that the effect of feeding with rich omega-3 unsaturated fatty acid sources on the number and size of corpus luteum and superovulation response were insignificant. This result of the present study were supported by Capovilla et al. (2006), Childs et al. (2008), Muller et al. (2009), Ghasemzadeh-Nava et al. (2011), Albuquerque et al. (2012), Salehi et al. (2016), Gandra et al. (2017).

In literature about the research topic, it is reported that progesterone synthesis increase in linolenic acid-rich ration-fed cows in general (Şirin \& Kuran 2004; Leroy et al. 2013). However, Ambrose et al. (2006) reported that plasma progesterone concentrations between groups remained unaffected by feeding with a ration enriched with $\alpha$-linolenic acid. This finding is consistent with the data obtained from the current research.

Similarly, Moriel et al. (2014) did not find any significant difference in serum progesterone levels of the groups in which dietary fatty acid was added to the rations and the control group to evaluate the effects of PUFA due to calcium salts on serum concentrations of progesterone and insulin in their study.

Ghasemzadeh-Nava et al. (2011) investigated the effects of polyunsaturated fatty acid addition to rations on plasma metabolites, ovarian function, and prostaglandin release in lactating cows. They found that the plasma estradiol, progesterone and $\mathrm{PGF}_{2 \alpha}$ levels were similar between the groups.

The results of the present study in terms of serum progesterone levels were found to be similar with the reports of Ambrose et al. (2006), Ghasemzadeh-Nava et al. (2011) and Moriel et al. (2014). In this case it could be interpreted that n-3 PUFA source used in this study may be converted to stearic acid, i.e. saturated state via biohydrogenation by rumen microorganisms for this different results (Staples et al. 1998).

\section{Conclusions}

As a result of this study, the effect of omega-3 source addition to donor cow rations on oocyte and embryo number and quality was evaluated and it was determined that feeding rich in unsaturated fatty acid source led to a decrease in quality of oocytes and the number of transferable embryos in donor cows. As a reason of this results it could be interpreted that linolenic acid may affect granulosa cells of follicles and causes a drop in plasma estrodiol levels which leads a delay in ovulation as a result of inadequate LH fluctuations in donor cows applied superovulation.

It is concluded that oocyte quality and embryo development may be adversely affected due to ovulation delay in donor cows fed by ration rich in omega-3 fatty acid. In addition, the possibility of the omega-3 PUFA source which might be converted to saturated stearic acid via biohydrogenation by rumen microorganisms should be considered. 
As can be understood from the results of the current research and the other studies about the topic, the effects of unsaturated fatty acid source addition on superovulation performance, embryo number and quality of donor cows ration are not clear. These contradictory results suggest that more in vivo advanced studies are needed on the subject.

\section{Acknowledgements}

This thesis study was supported by Republic of Turkey, Ministry of Agriculture and Forestry-General Directorate of Agricultural Research and Policies TAGEM - HAYSUD - AR-GE -15.A02.P03.03 project number.

\section{References}

Albuquerque K P, do Prado I N, do Prado R M, Cavallieri F L B, Rigolon L P \& Barbosa O R (2012). Superovulatory response, production and quality of embryos of cows fed on linseed or canola seed supplemented diets. Acta Scientiarum Animal Sciences 34(3): 321-327 http://doi.org/10.4025/actascianimsci.v34i3.13372

Ambrose D J, Kastelic J P, Corbett R, Pitney P A, Petit H V, Small J A \& Zalkovic P (2006). Lower pregnancy losses in lactating dairy cows fed a diet enriched in linoleic acid. Journal of Dairy Science 89: 3066-3074 http://doi.org/10.3168 / jds.S0022-0302 (06) 72581-4

AOAC (1998). Official methods of analysis. $16^{\text {th }}$ ed. $4^{\text {th }}$ revision, Association of Official Analytical Chemists, Washington DC, USA

Bidarimath M \& Glover K (2015). Effect of omega-3 fatty acids on the ovaries of lactatıng dairy cows. Retrieved in December, 20,2016 from https://www.researchgate.net-publication-284673150 http://doi.org/10.13140/RG.2.1.3988.1044

Boland M P \& Lonergan P (2003). Effects of nutrition on fertility in dairy cows. Advances in Dairy Technology 15: 19-33

Bülbül B \& Dursun Ş (2005). Factors affecting superovulation response in cows. Livestock Research Journal 15(1): 16-25 In Turkısh

Bó G A, Baruselli P S, Moreno D, Cutaia L, Caccia M, Tríbulo R, Tríbulo H \& Mapletoft R J (2002). The control of follicular wave development for selfappointed embryo transfer programs in cattle. Theriogenology 57(1): 53-72 http://doi.org/10.1016/j.theriogenology.2013.09.020

Capovilla L C T, Rigolan L P, Cavalieri F L B, Macedo F A F, Albuquerquue K P, Lourenço F J \& Santello G (2006). Superovulation and embryos viability of santa ines ewes fed with essential fatty acids. Academical Journal 4(1): 65-73

Childs S, Carter F, Lynch C O, Sreenan J M, Lonergan P, Hennessy A A \& Kenny D A (2008). Embryo yield and quality following dietary supplementation of beef heifers with n-3 polyunsaturated fatty acids (PUFA). Theriogenology 70(6): 992-1003 http://doi.org/10.1016/j.theriogenology.2008.06.008

Elis S, Freret S, Desmarchais A, Maillard V, Cognie J, Briant E, Touze J L \& Dupont M (2016). Efect of a long chain n-3 pufa-enriched diet on production and reproduction variables in holstein dairy cows. Animal Reproduction Science 164: 121-132 http://dx.doi.org/10.1016/j.anireprosci.2015.11.020

Ergün Y \& Erdoğan Z (2001). The effect of feeding on fertility in dairy cattle - I: Energy, protein and fertility relationship. Bulletin Veterinary Journal October: 9-12 In Turkısh

Fouladi-Nashta A A, Gutierrez C G, Gong J G, Garnsworthy P \& Webb R (2007). Impact of dietary fatty acids on oocyte quality and development in lactating dairy cows. Biology of Reproduction 77(1): 9-17 http://doi.org/10.1095/biolreprod.106.058578

Gandra J R, Verdurico L C, Mingoti R D, Takiya C S, Gardinal R, Vendramini T H A, Barletta R V, Visintin J A \& Rennóve F P (2017). Whole flaxseed, raw soybeans and calcium salts of fatty acids supplementation for transition cows: Follicle development and embryo quality. Italian Journal of Animal Science 16(4): 538-545 http://doi.org/10.3168 / jds.2015-9974

Ghasemzadeh-Nava H, Fatahnia F, Nikkhah A \& Zamiri M J (2011). Effects of dietary polyunsaturated fatty acids on ovarian function and prostaglandin secretion in lactating dairy cows. International Journal of Veterinary Research 5(2): 129-135

Hasler J F (2004). Factors influencing the success of embryo transfer in cattle. Retrieved in November, 25, 2014 from

Hiçcan Ö \& Yıldız G (2016). Effects of energy balance on breeding in dairy cows. Retrieved in December, 28, 2016 from News / livestock / dairy-cows-energy-balance-effects on http://www.tarimdanhaber.com/ In Turkısh

IETS (2010). Bovine in vivo embryo slide set tutorial. Retrieved in December, 21, 2016 from http://www.iets.org.

Kanagawa H, Shimohira I \& Saitoh N (1995). Manual of bovine embryo transfer. National Livestock Breeding Center MAFF, JICA-Japan

Kaymaz M (2015). Obstetrics and gynecology in farm animals. Kaymaz M, Assisted reproductive techniques, $2^{\text {nd }}$ Edition, Medipres Printing Publishing Ltd. Şti., Malatya s. 695-811 In Turkısh

Leroy J L, Sturmey R G, Van Hoeck V, De Bie J, McKeegan P J \& Bols P E J (2013). Dietary lipid supplementation on cow reproductive performance and oocyte and embryo viability: A real benefit? Animal Reprodiction Science 10(3): 258-267 http://doi.org/10.1111/rda.12308

Mattos R, Staples C R \& Thatcher W W (2000). Effects of dietary fatty acids on reproduction in ruminants. Reviews of Reproduction 5(1): 38-45 https://doi.org/10.1530 / ror.0.0050038

Moriel P, Cappellozza B I, Ferraretto L F, Aboin A C, Vieira F V R, Rodrigues R O, Cooke R F \& Vasconcelos J L M (2014). Effects of supplementation of calcium salts of polyunsaturated fatty acids on serum concentrations of progesterone and insulin of pregnant dairy cows. Revista Brasileira de Zootecnia 43(1): 20-26 https://doi.org/10.1590/S1516-35982014000100004

Muller M, Prado I N, Júnior A R L, Silva R R, Capovilla L C T, Rigolon L P, Cavalieri F L B \& Marques J A (2009). $\Omega-3$ nd $\Omega-9$ on performance, superovulatory response and embryo production in nellore heifers. Archivos de Zootecnia 58(222): 241-252

NRC (2001). Nutrient Requirement of Dairy Cattle. $7^{\text {th }}$ revised ed., National Academy Press, Washington DC

Petit H V, Cavalieri F B, Santos G T, Morgan J \& Sharpe P (2008). Quality of embryos produced from dairy cows fed whole flaxseed and the success of embryo transfer. Journal of Dairy Science 91(5): 1786-1790 http://doi.org/10.3168/jds.2007-0782

Rivera F A, Mendonça L G, Lopes G J R, Santos J E, Perez R V, Amstalden M, Calderon A C \& Chebel R C (2011). Reduced progesterone concentration during growth of the first follicular wave affects embryo quality but has no effect on embryo survival post transfer in lactating dairy cows. Reproduction 141(3): 333-342 http://doi.org/10.1530/REP-10-0375

Salehi R, Colazo M G, Tsoi S, Behrouzi A, Tsang B K, Dyck M K, Oba M \& Ambrose D J (2016). Morphologic and transcriptomic assessment of bovine embryos exposed to dietary long-chain fatty acids. Reproduction 152: 715-726 http://doi.org/10.1530 / REP-160093 
Santos J E P, Cerri R L \& Sartori R (2008). Nutritional management of the donor cow. Theriogenology 69(1): 88-97 http://doi.org/10.1016/j.theriogenology.2007.09.010

Smith O B \& Akinbamijo O O (2000). Micronutritients and reproduction in farm animals. Animal Reproduction Science 60-61: 549-560 http://doi.org/10.1016 / s0378-4320 (00) 00114-7

Staples C R, Burke J M \& Thatcher W W (1998). Influence of suplemental fats on reproductive tissue and performance of lactating cows. Journal of Dairy Science 81(3): 856-871 http://doi.org/10.3168 / jds.S0022-0302 (98) 75644-9

SPSS for Windows (1999). Base System User's Guide, Release11.5, PSS Inc. Chicago, USA

Şirin E \& Kuran M (2004). The effect of dietary fatty acids on reproductive functions in ruminants. $4^{\text {th }}$ National Animal Science Congress, 13 September, İsparta s. 54-61 In Turkısh

Takahashi M, Sawada K, Kawate N, Inaba T \& Tamada H (2013). Improvement of superovulatory response and pregnancy rate after transfer of embryos recovered from japanese black cows fed rumen bypass polyunsaturated fatty acids. Journal of Veterinary Medical Science 75(11): 1485-1490 http://doi.org/10.1292/jvms.12-0235

Tessaro F H, Ayala T S \& Martins J O (2015). Lipid mediators are critical in resolving inflammation: A review of the emerging roles of eicosanoids in diabetes mellitus. Biomed Research International 2015: 8 http://doi.org/10.1155 / 2015/568408

Tur İ (2014). Koyun rasyonundaki ham protein oranının kan üre nitrojen, ovaryum fonksiyonu, fertilizasyon, uterus fizyoloji ve embriyo kalitesi üzerine etkisi. Doktora tezi, Basılmamış, Selçuk Üniversitesi Sağlık Bilimleri Enstitüsü, Konya

Urlep Z \& Rozman D (2013). The interplay between circadian system, cholesterol synthesis, and steroidogenesis affects various aspects of female reproduction. Front Endocrinol (Lausanne) 4: 111 http://doi.org/10.3389 / fendo.2013.00111

(C) 2021 by the authors. Licensee Ankara University, Faculty of Agriculture, Ankara, Turkey. This article is an open access article distributed under the terms and conditions of the Creative Commons Attribution (CC BY) license (http://creativecommons.org/licenses/by/4.0/). 